SULUH Jurnal Bimbingan Konseling, April 2017, Volume 3 Nomor 1 (6-11)

http://jurnal.umpalangkaraya.ac.id/ejurnal/suluh

\title{
PERILAKU TANTRUM PADA ANAK TK RAHMAT AL-FALAH KELOMPOK B PALANGKA RAYA
}

\author{
Puspita Seni, Dina Fariza. TS
}

\begin{abstract}
ABSTRAK
Penelitian ini bertujuan untuk mendeskripsikan bentuk perilaku tantrum pada anak TK Rahmat Al-Falah kelompok B Palangka Raya. Fokus penelitian ini adalah bagaimana perilaku tantrum pada anak TK Rahmat Al-Falah kelompok B Palangka Raya. Penelitian ini menggunakan pendekatan kualitatif dengan jenis penelitian deskriptif. Objek penelitian ini adalah anak yang mengalami tantrum. Di TK Rahmat Al-Falah terdapat dua anak tantrum. Data-data dikumpulkan melalui observasi, wawancara, dan dokumentasi. Data yang terkumpul dianalisis secara deskriptif kualitatif menggunakan model analisis interaktif. Data-data hasil penelitian diuji keabsahannya dengan triangulasi sumber.

Hasil penelitian menunjukkan bahwa terdapat dua anak tantrum di TK Rahmat Al-Falah dengan perilaku yaitu : 1) menangis, 2) berteriak-teriak, 3) meninju teman, serta 4) melempar benda. Faktor penyebabnya yaitu : 1) tidak terpenuhinya apa yang diinginkan, 2) merasa kecewa, 3) berebut mainan, 4)diganggu teman serta 5) jika dimarahi guru. Upaya yang dilakukan guru untukmengatasi perilaku tantrum yaitu : 1) memberikan pujian, 2) menegur, 3) mengalihkan perhatian anak serta 4) meminta teman lain untuk tidak mengganggunya. Upaya yang dilakukan orangtua cenderung tidak ada, terdapat sikap acuh tak acuh bahkan membela perilaku anak. Hambatan yang dihadapi guru yaitu: guru merasa terkendala (bingung) dalam mengatasi perilaku tantrum

(C) Universitas Muhammadiyah Palangkaraya
\end{abstract}

\section{Kata Kunci: Perilaku Tantrum Anak}

PENDAHULUAN

Rentang usia 0-6 tahun merupakan masa emas perkembangan anak, yang apabila pada masa tersebut anak diberi pendidikan dan pengasuhan yang tepat akan menjadi modal penting bagi perkembangan anak di kemudian hari. Pembelajaran tentang sikap, perilaku dan dan bahasa yang baik sehingga akan terbentuknya kepribadian anak yang baik pula, perlu diterapkan sejak dini. Orangtua merupakan pendidik yang paling utama, guru serta teman sebaya yang merupakan lingkungan kedua bagi anak. Hal ini sesuai dengan apa yang kita lihat sekarang bahwa orang yang paling penting bagi anak adalah orangtua, guru dan teman sebaya dari merekalah anak mengenal sesuatu yang baik dan tidak baik. Pendidikan dalam keluarga yang baik dan benar akan sangat berpengaruh pada perkembangan pribadi dan sosial anak.

Aspek perkembangan pada anak yang perlu distimulasi diantaranya 
adalah aspek nilai agama, moral, bahasa, sosial emosional, kognitif dan fisik. Apabila kelima aspek tersebut tidak distimulasi secara optimal maka anak akan mengalami suatu hambatan dalam perkembangannya. Lingkungan sangat berpengaruh dalam pencapaian perkembangan anak. Anak yang tidak beradaptasi dengan lingkungannya akan mengalami tekanan tersendiri. Oleh karena itu, anak cendrung akan melakukan hal-hal yang diluar kendalinya. Dalam artian, anak tidak mampu lagi mengendalikan emosi dalam dirinya. Apalagi pada masa tersebut anak-anak sedang mengalami suatu fase yang bernama tantrum.

Temper tantrum atau yang biasa disebut tantrum dapat didefinisikan sebagai "ledakan amarah" dan ledakan itu terjadi pada semua tahapan usia. Ledakan ini dapat terjadi pada semua tahapan usia. Pada anak, tingkah laku terburuk biasanya terjadi pada rentang usia 18 bulan hingga 3 tahun. Pada usia 5 hingga 6 tahun, tingkah laku buruk ini masih terjadi, namun sangat tidak biasa (Hayes, 2003:12). Tantrum terjadi pada anak yang aktif dengan energi yang melimpah (Hasan, 2011:185). Menurut Hurlock (1998:115), tantrum adalah ledakan amarah yang kuat, ketakutan yang hebat dan iri hati yang tidak masuk akal. Tantrum merupakan gangguan tingkah laku yang terjadi pada anak usia tiga sampai tujuh tahun, gangguan ini ditandai dengan adanya suatu pola tingkah laku disosial, agresif atau menentang yang berulang dan menetap (Maslim, 2003:137).

Menurut Rini Hildayani, dkk (2009) ada 3 jenis temper tantrum yaitu:
Manipulative, Verbal Frustration Tantrum, dan Temperamental Tantrum. Tantrum dapat menjadi masalah tersendiri ketika muncul dengan frekuensi, intensitas, dan dalam waktu yang relatif melebihi yang biasanya terjadi pada anak seusianya. Untuk itu sebagai orangtua maupun pendidik harus mengetahui apa itu tantrum dan bagaimana sikap yang harus dilakukan orangtua maupun pendidik untuk menangani atau mengurangi perilaku tantrum tersebut.

Tantrum merupakan salah satu ciri anak bermasalah dalam perkembangan emosi mereka. Menurut Rosmala Dewi (2005:95), ciri-ciri tantrum yaitu : marah berlebihan, takut yang sangat kuat, malu serta hipersensitif. Apabila frekuensi dan intensitas tantrum tidak berlebihan maka perilaku tersebut akan hilang dengan sendirinya seiring dengan bertambahnya usia atau kemampuan anak untuk mengendalikan emosinya. Namun, perilaku tantrum tidak boleh dibiarkan apabila intensitas dan frekuensinya tinggi pada anak karena akan mengakibatkan anak tidak mampu mengendalikan dan meluapkan emosi secara wajar.

Perasaan frustasi anak berasal dari hasratnya untuk segera melakukan apapun yang ada di dalam pikirannya. Frustasi menimbulkan banyak ketegangan yang harus diungkapkan dengan cara menjatuhkan diri ke lantai, bergerak-gerak dengan liar, dan menjerit sekeras-kerasnya. Cara tersebut sangat ampuh untuk segera melepaskan ketegangan. Anak-anak menyesuaikan perilakunya dengan perilaku 
orangtuanya. Orangtua yang suka mengamuk mungkin akan mempunyai anak balita yang juga senang mengamuk (Penney Hames, 2003:7).

Perspektif psikologi orangtua yang mengasuh tidak konsisten dapat menyebabkan anak mengalami temper tantrum. Anak yang terlalu dimanjakan dan selalu mendapatkan apa yang ia inginkan dapat mengalami tantrum jika suatu kali permintaannya, ditolak. Keadaan lain yang juga meningkatkan frekuensi temper tantrum adalah sikap orangtua yang cenderung mengkritik dan terlalu cerewet (Muzakkir, 2008:201).

Pada kenyataannya anak akan melakukan tantrum apabila keinginannya tidak terpenuhi oleh orangtuanya. Biasanya anak menggunakan tantrum sebagai trik untuk mendapatkan sesuatu dari orangtua. Sebagai orangtua dan pendidik, kita seharusnya dapat memberikan pemahaman kepada anak apabila tidak semua keinginan yang dikehendakinya serta merta dapat terwujud. Kegagalan komunikasi antara anak dan orangtuanya menjadikan salah satu faktor penyebab yang dapat meningkatkan intensitas tantrum.

Berikut adalah beberapa faktor yang menyebabkan terjadinya tantrum menurut Hasan (2011:187) yaitu: terhalangnya keinginan untuk mendapatkan sesuatu, ketidakmampuan anak mengungkapkan diri, tidak terpenuhinya kebutuhan, pola asuh orangtua, anak merasa lelah, lapar atau dalam keadaan sakit. Hurlock (2011: 222) situasi yang menimbulkan tantrum antara lain: Rintangan terhadap gerak yang diinginkan anak, baik rintangan itu berasal dari orang lain atau dari ketidakmampuan diri sendiri.

Menurut Penny Hames (2003:73), hal-hal yang membuat anak frustasi sehingga dapat menyebabkan perilaku tantrum atau amarah dan terutama sering terjadi pada masa anak-anak balita adalah: 1) tidak mendapatkan yang dia inginkan, 2) tidak mampu melakukan sendiri, 3) menginginkan kita melakukan sesuatu yang tidak dapat atau tidak ingin kita lakukan, 4) tidak mengetahui yang dia inginkan, 5) tidak mampu menjelaskan apa yang dia inginkan, 6) tidak mampu mengendalikan sesuatu, 7) disalah mengerti, 8) kebosanan, 9) kelelahan, 10) lapar, dan 11) sakit. Maka dapat disimpulkan faktor penyebab anak mengalami tantrum antara lain: (1) faktor fisiologis, yaitu lelah, lapar atau sakit (2) faktor psikologis, antara lain anak mengalami kegagalan, dan orangtua yang terlalu menuntut anak sesuai harapan orangtua; (3) faktor orangtua, yakni pola asuh; (4) faktor lingkungan, yaitu lingkungan keluarga dan lingkungan luar rumah.

Intensitas tantrum anak yang tinggi dapat menimbulkan tekanan tersendiri bagi orangtua ataupun pendidik dan seringkali justru memancing kemarahan dari dari para orangtua. Sehingga yang terjadi bukannya orangtua meredam tantrum namun justru orangtua terpancing emosi. Anak yang mengalami masalah dengan orangtuannya, adakalanya tidak dapat menyalurkan emosinya dengan tepat, salah satu bentuknya adalah tantrum. Ia membutuhkan waktu yang 
cenderung lama untuk beradaptasi dan mengalami kesulitan dalam mengekspresikan diri.

Perilaku tantrum merupakan hal yang wajar terjadi namun apabila tidak diatasi akan mempengaruhi anak pada perkembangan yang selanjutnya. Hurlock (2009:211) menjelaskan bahwa pengaruh emosi terhadap penyesuaian pribadi dan sosial anak yaitu: 1) ketegangan emosi mengganggu ketrampilan motorik, 2) emosi mengganggu aktivitas mental, 3) emosi mempengaruhi suasana psikologis, 4) reaksi emosional apabila diulang-ulang akan berkembang menjadi kebiasaan.

Berdasarkan wawancara yang peneliti lakukan kepada Guru/Wali kelas yang berada di TK Rahmat AlFalah, peneliti mendapatkan seorang anak dengan ciri-ciri suka mengamuk, menjerit, berteriak-teriak melemparlempar barang, memukuli orangtuanya jika tidak terpenuhi keinginannya, suka berebut dengan teman dan merengut jika apa yang dia inginkan tidak terpenuhi. Dengan ciri-ciri yang peneliti lakukan melalui wawancara awal dari guru/wali kelas maka anak tersebut tergolong anak temper tantrum.

Saat dilakukannya observasi awal juga terdapat ciri-ciri tantrum yang muncul dari satu anak yang terdapat di kelas B seperti : merengut atau mudah marah, menangis, melempar barang serta memukul. Ketika anak mengalami dan menunjukkan perilaku tantrum, sikap orangtua acuh, bahkan terkesan membela si anak. Orangtua cenderung tidak terlalu memahami dengan perkembangan anak. Dari pihak guru pun merasa bingung dengan Puspita Seni, Dina Fariza. TS penanganan saat anak melakukan perilaku tantrum di sekolah, baik itu kegiatan di luar maupun di dalam kelas.

Mendasarkan pada kondisi tersebut maka peneliti bermasksud untuk melakukan peneltian dengan judul Perilaku Tantrum Pada Anak Tk Rahmat Al-Falahkelompok B Palangka Raya

\section{METODE PENELITIAN}

Pendekatan penelitian yang digunakan dalam penelitian ini adalah pendekatan kualitatif. Moleong (2005:6) menjelaskan penelitian kualitatif yaitu penelitian yang bermaksud untuk memahami fenomena tentang apa yang dialami oleh subjek penelitian secara holistik, dan dengan cara deskripsi dalam bentuk kata-kata, bahasa, pada suatu kontek khusus yang alamiah dan dengan memanfaatkan berbagai metode alamiah.

Menurut Suharsimi Arikunto (2005:243), penelitian deskriptif adalah penelitian yang dimaksudkan untuk mengumpulkan informasi mengenai status suatu gejala yang ada, yaitu gejala menurut apa adanya pada saat penelitian dilaksanakan. Sudjana (2004:64), mengungkapkan bahwa penelitian deskriptif adalah penelitian yang berusaha mendeskripsikan segala suatu gejala, peristiwa, atau kejadian yang terjadi pada saat sekarang.

$$
\text { Moleong }
$$
mendeskripsikan subjek penelitian sebagai informan, yang artinya orang pada latar penelitian yang dimanfaatkan untuk memberikan informasi tentang situasi dan kondisi latar penelitian. Subjek pada penelitian ini adalah 
Kepala Sekolah, Guru/Wali kelas dan Orangtua/Wali murid, dan peserta didik NAF dan RF sebagai objek penelitian. Dipilihnya NAF dan RF sebagai objek penelitian karena ciri-ciri perilaku tantrum yang muncul ada pada kedua anak tersebut. Untuk mengumpulkan data yang diperlukan dalam penelitian ini, peneliti menggunakan beberapa cara, yaitu wawancara, observasi, dan dokumentasi

\section{HASIL DAN PEMBAHASAN}

Berdasarkan hasil wawancara, observasi dan dokumentasi terdapat informasi mengenai latarbelakang anak tantrum. Di TK Rahmat Al-Falah Palangka Raya terdapat dua anak yang mempunyai ciri-ciri tantrum, yang terdapat di kelompok B1 berinisial RF dan kelompok B2 berinisial NAF

\section{Perilaku tantrum RF}

Bentuk perilaku tantrum pada RF yaitu berteriak, menangis, kondisi tersebut terjadi karena apa yang di inginkan tidak terpenuhi, dan tidak dituruti sehingga muncul perilaku tersebut. Dan upaya yang dilakukan guru yaitu dengan membujuk dan mengalihkan perhatian dari apa yang diharapkan oleh anak tersebut. Berdasarkan hasil observasi yang telah dilakukan, peneliti kurang bisa mendapatkan jawaban mengenai upaya orangtua untuk mengatasi perilaku anak karena sikap dari orangtua yang membela dan tertutup atas perilaku anak

2. Perilaku NAF

Perilaku tantrum yang muncul pada NAF yaitu: menangis, melempqar
memukul/meninju, tersebut meuncul dikarenakan merasa dirinya terganggu dan juga karean tidak bisa mengungkapkan apa yang dirasakannya. Hal yang bisa dilakukan oleh guru yaitu dengan mendiamkan sementara waktu, mengambil benda yang memiliki kemungkinan untuk dilempar oleh anak tersebut.

Berdasarkan hasil observasi yang telah dilakukan, guru terlihat kewalahan dengan perilaku anak yang semakin menjadi-jadi saat ditegur dan diberi nasihat oleh guru. Kadang dengan upaya guru dengan memuji, anak akan sedikit berkurang perilaku tantrumnya namun tidak jarang anak tidak terkendali dengan upaya yang telah dilakukan oleh guru. Oleh sebab itu, guru kadang cenderung mendiamkan karena merasa kewalahan dengan sikap anak yang lebih menjadi-jadi.

\section{KESIMPULAN}

Bentuk perilaku tantrum pada anak TK Rahmat Al-Falah seperti menangis dengan keras, berteriakteriak, melempar benda, dan meninju teman. Perilaku tantrum muncul jika anak mencari perhatian, menginginkan sesuatu namun tidak bisa dimiliki atau terhalang keinginannya, kekecewaan. Perilaku tantrum pada anak juga muncul saat anak merasa tersinggung, merasa diganggu atau terganggu, dan tidak mampu mengungkapkan perasaannya dengan kata-kata atau ekspresi yang diinginkannya

DAFTAR PUSTAKA 
Hurlock. $1998 . \quad$ Psikologi

Perkembangan

Suatu

Pendekatan Sepanjang Rentang

Kehidupan. Jakarta : Erlangga. 2009. Perkembangan Anak.

Jakarta : Erlangga. 2011.

Psikologi

Perkembangan:

Suatu

Pendekatan Sepanjang Rentang

Kehidupan. Edisi Kelima (Alih

Bahasa : Istiwidayanti dan

Soedjarwo). Jakarta: Erlangga.

Hayes. 2003. Tantrum Panduan

Memahami dan Menangani

Ledakan Emosi Anak (Alih

Bahasa : Hamiyn Octopus).

Jakarta : Erlangga.

Hasan. 2011. Pendidikan Anak Usia

Dini. Jogjakarta: Diva Press.

Maslim. 2003. Buku Saku Diagnosis

Gangguan Jiwa, Rujukan Ringkas PPDGJ-III. Jakarta : Bagian Ilmu Kedokteran Jiwa FK Atma Jaya.

Moleong. 2005. Metodologi Penelitian Kualitatif. Bandung : PT Remaja Rosdakarya.

.2010. Metode Penelitian Kualitatif. Bandung : PT Remaja Rosdakarya.

Muzakkir. 2008. Terapi Musik Melalui Metode Orff : Studi Kasus Program Terapi Pada Anak Yang Mengalami Temper Tantrum di Cimahi Jawa Barat. PPDGJ III. Jakarta : Bagian Ilmu Kedokteran Jiwa FK Atma Jaya. PT Gramedia.

Penney, Hames. 2005. Menghadapi dan Mengatasi Anak Yang Suka Ngamuk. Jakarta : PT Gramedia
Rosmala Dewi. 2005. Berbagai Masalah Anak Taman KanakKanak. Jakarta : Depdiknas.

Rini Hildayani, dkk. 2009. Penanganan Anak Berkelainan (Anak Dengan Kebutuhan Khusus). Jakarta : Universitas Terbuka.

Sudjana. 2004. Manajemen Program Pendidikan Untuk Pendidikan Non formal Dan Pengembangan Sumber Daya Manusia. Bandung : Falah Production.

Suharsimi Arikunto. 2005. Manajemen Penelitian. Jakarta : Rineka Cipta. 